\title{
Evaluation of the Pumpkin Seed Membrane as a Nutrient in the Fruit Fly Model, Fed With High Fat Diet
}

\author{
Eda GÜNEŞ ${ }^{1 *}$, Şerife BİÇER BAYRAM ${ }^{2}$ \\ *Corresponding Author: egunes@erbakan.edu.tr \\ ${ }^{1 *}$ Necmettin Erbakan University, Faculty of Tourism, Department of Gastronomy and Culinary Arts, KONYA \\ Orcid No: 0000-0001-7422-9375 / egunes@erbakan.edu.tr \\ ${ }^{2}$ Necmettin Erbakan University, Institute of Social Sciences, Department of Gastronomy and Culinary Arts, \\ KONYA \\ Orcid No: 0000-0002-5199-4100/ serfebicer@gmail.com
}

\begin{abstract}
The pumpkin seed membrane (PSM), which is high in water retention in the study, was recycled as waste, intended to be used in terms of target-non-target creatures and to determine its effect on resistance formation. Nowadays, when fat intake is steadily increasing through nutrition, increased use of fat makes an individual vulnerable to stress. The study determined the effect of additional taken waste/nutrients on oxidative stress in obese individuals. The fatty diet and pumpkin seed effect were trialed in the model organism in the study. The amount of Malondialdehyde (MDA) and total oxidation (TOS) and total antioxidant effect (TAS) and glutathione-S-transferase (GST) activity in larvae, pupae, and adult of Drosophila melanogaster were calculated by adding different proportions of PSM $(0.05-2 \mathrm{~g})$ and fat $(20 \%)$ to the diet. According to the data obtained: It was determined that the period with the highest oxidative stress index (OSI) is the pupae (pupae> larvae> female > male), the amount of lipid peroxidation (MDA) is higher in females, moreover, the third larvae is the most resistant stage. The results have shown that waste of seed mambrane can't be useful in vivo as a nutrient due to usage limitation.
\end{abstract}

Keywords: Drosophila, glutathione-S-transferase, lipid peroxidation, nuts-pumpkin, oxidative stress index

\section{Yüksek Yağlı Diyetle Beslenen Meyve Sineği Modelinde Besin Olarak Kabak Çekirdeği Zarının Değerlendirilmesi}

\begin{abstract}
Öz: Çalışma atık olarak geri dönüştürülebilen ve su tutma oranı yüksek olan kabak çekirdeği zarı (PSM), hedefdışı canlılar açısından kullanılması ve direnç oluşumuna etkisinin belirlenmesi amacıyla yapılmıştır. Beslenme yoluyla yă̆ alımının giderek arttığı günümüzde, artan yağ kullanımı bireyi strese karşı savunmasız hale getirmektedir. Obez bireylerde ek alınan atık/besin maddelerinin oksidatif stres üzerindeki etkisi de çalışma ile belirlenmiştir. Çalışmada model organizmada yağlı diyet ve kabak çekirdeği etkisi denenmiştir. Drosophila melanogaster diyetine \%20 yağ ve farklı oranlarda PSM (0.05-2 g) eklenerek larva, pupa ve yetişkin bireylerde Malondialdehit (MDA) ve toplam oksidasyon (TOS) miktarı, toplam antioksidan etki (TAS) ve glutatyon-Stransferaz (GST) aktivitesi hesaplanmıştır. Elde edilen verilere göre: Oksidatif stres indeksinin (OSI) en yüksek olduğu dönemin pupa (pupa>larva >dişi>erkek) olduğu, kadınlarda lipid peroksidasyon (MDA) miktarının daha yüksek olduğu, ayrıca üçüncü larva en dirençli evre olduğu belirlenmiştir. Sonuçlar, kullanım sınırlaması nedeniyle tohum zarı atıklarının in vivo besin maddesi olarak yararlı olamayacağını göstermiştir.
\end{abstract} indeksi

Anahtar Kelimeler: Drosophila, glutatyon-S-transferaz, lipid peroksidasyonu, findık-kabak, oksidatif stres

\section{Introduction}

Food products go through many stages until they arrive at the table from the field, where various waste can occur during the production-consumption process. Recently, studies on recycling food waste have become important (Töke and Ergülen, 2020; Güneysu, 2020; Filimonau et al., 
2021). Making food waste available by recycling alongside being of alarming size has set the stage for biological and biomedical research (Qiu et al., 2019; Güneş, 2020). Determining the availability of sustainable waste with little physiological impact on living things in a laboratory environment is important to solve or reduce this problem. Pumpkin seeds (Cucurbita реро L.) oil and bark are a product used for herbal treatment in various diseases and as a feed additive (Syed et al., 2019; ValdezArjona and Ramírez-Mella, 2019; Alshehry, 2020; Majid et al., 2020). While the use of the pumpkin seed membrane (PSM) is available in the paper and clothing industry, there are few studies on the possibility of a nutritional environment (Güneş and Biçer Bayram, 2019).

However, nutrition affects the quality of life of living as an important factor in the occurrence of chronic diseases (Blüher, 2020). Compounds added to standard nutrients are increasing in proportion to increased nutrient intake. Excessive fat intake, especially with diet, has become a global problem (Genç and Köse, 2019; Bocharova and Teplyakova, 2020; Sağlam and Soylu, 2019; Blüher, 2020; Bendor et al., 2020). Chronic diseases, particularly obesity, are on the rise because of an imbalance in the number of calories taken and calories consumed, with increased work time and inactivity at home, especially during the last one-year COVID-19 pandemic period. A high-fat diet (HFD) has been associated with obesity, diabetes, and heart diseases, it has been stated, which can increase aging and oxidative stress by researchers (Alzoubi et al., 2018a; Lorizola et al., 2018; Cormier et al., 2021). Phytochemical herbal products and compounds that have an antioxidant effect, such as polyphenol, are used to reduce stress and body weight in living things or to increase the lifespan (Chen et al., 2017; Chung et al., 2018; Güneş, 2020; Mohamad et al., 2020; Zhang et al., 2020; Salama et al., 2020). Therefore, the oxidative stress of plant products and the nutritional relationship with the fatty diet is a current issue studied by researchers (Koh et al., 2013; Llana-Ruiz-Cabello et al., 2015; Maduagwuna et al., 2020; Uysal ve Çelik, 2021). Therefore, the availability of the supplemental product needs to be evaluated well.

Model organisms are organisms from which biological events and processes can be easily studied and inferred, without ethical need (Matthews et al., 2020; Nainu et al.,2020). In studies of obesity-induced by oxidative stress in nutrition, in determining the effectiveness of phytochemicals, they are used fruit flies as models of human disease (Drosophila melanogaster Meigen) (Siddique et al., 2005; Hazır et al., 2020). Experimental use of $D$. melanogaster, which 
contains tissues corresponding to human tissues, is also increasing in the study of some diseases (obesity, diabetes) that occur because of today's dietary habits (Lüersen et al., 2019; Poças et al., 2020; Cormier et al., 2021; Güneş, 2021). They are also considered to be used in COVID-19 treatment and drug production in recent studies (Nainu et al., 2020).

When evaluating the availability of pumpkin seed membrane as a nutrient environment due to its strong water retention capacity for in vitro studies (Çankaya and Özcan, 2017; Syed et al., 2019; Alshehry, 2020), tried determining the effect on oxidative stress (malondialdehyde-MDA, glutathione-S-transferase-GST, total antioxidant level-TAS, total antioxidant level-TOS, oxidative stress index-OSI) in the obese model. Thus, suggestions have been developed for usage possibilities according to the resistance of the insect fed with PSM waste.

\section{Material and Method}

\subsection{Material}

In the study, commercial PSM was received by Pinar nuts, Nevşehir type in 2018-2019. After PSM was sterilized (30$40{ }^{\circ} \mathrm{C}$ ), and added to foods without freezing. D. melanogaster's strain $\left(\mathrm{W}^{1118}\right)$ was incubated in $50 \mathrm{ml}$ falcon tubes with $25 \pm$ $2^{\circ} \mathrm{C}$ and $60 \%-70 \%$ relative humidity, $12 / 12$ hours light/dark photoperiod. The standard nutrient medium (SNM: mashed potatoes, sucrose, dry yeast, agar, nipagin, and ascorbic acid) prepared for culture food was used as described by Güneş and Büyükgüzel (2017). SNM was also used as an experimental diet and as a negative control group (1).

In the study, palmitic acid (20\%, HFD, positive control group 2) was dissolved within Tween- 80 and added to the hot SNM (Sun et al., 2010). Trial design groups; PSM 0.05 g/L (3), PSM 2 g/L (4), PSM $0.05 \mathrm{~g} / \mathrm{L}+$ HFD (5), PSM 2 g/L + HFD (6) consist of these ingredients. The amount of PSM and HFN use were determined similar to the previous study (Güneş and Biçer Bayram, 2021). The females and males (5/1: about 100 individuals per bottle under carbon dioxide anesthesia) were taken for the culture, and they were mated for $48 \mathrm{~h}$ and the eggs were collected after six hours. Flies $1^{\text {st }}$ stage larvae (100 individuals per bottle) were inoculated with experimental nutrient design and grown to the adult stage. $3^{\text {rd }}$ stage larvae, pupae, and 3-day old virgin adult (20 female/20 male) stages were used for each trial in the biochemical analysis (lipid peroxidation product: MDA amount, antioxidant enzyme: GST activity, oxidative stress index: OSI, total antioxidant level and total oxidation level: TAS / TOS).

Samples were extracted with homogenization buffer $(1.15 \%$ potassium 
chloride, $25 \mathrm{mM}$ dipotassium hydrogen phosphate, $5 \mathrm{mM}$ ethylenediamine tetraaceticacid, $2 \mathrm{mM}$ phenethylylsulphonyl, $2 \mathrm{~mm}$ dithiillotenitol, $\mathrm{pH}:$ 7.4) in an ultrasonic homogenizer at $+4^{\circ} \mathrm{C}$. MDA amount (Jain and Levine method, 1995, 532 $\mathrm{nm}$ ), GST (EC 2.5.1.18) activities (Habig et al.,1974, $340 \mathrm{~nm}$ ), and total protein (FolinLowry, 1951, $600 \mathrm{~nm}$ ) of samples were measured using a spectrophotometer. TOS $\left(\mu \mathrm{mol} \mathrm{H}_{2} \mathrm{O}_{2} \mathrm{Eq} / \mathrm{L}\right.$ ) and TAS (mmol Trolox $\mathrm{Eq} / \mathrm{L}$ ) of samples were measured, and oxidative stress index $(\mathrm{OSI}=\mathrm{TOS} / \mathrm{TAS})$ was determined to the standard formula (Chen et al., 2017; Erel, 2005; Özgün et al., 2013; Güneş, 2021).

The statistical analysis of triplicate experiments included one-way analysis of variance (ANOVA) using SPSS software, followed by the least significant difference (LSD) test to identify significant differences between means. "Kruskal-Wallis" test was used to determine the changes in the stages of MDA and GST analysis. The significance of the mean between groups and stages was evaluated at the level of 0.05 .

\section{Results}

About $0.05 \mathrm{~g}$ of PSM has no negative effects on the development of life, while the negatively affecting amount $\left(\mathrm{LC}_{50}\right)$ is $2 \mathrm{~g}$ (Güneş and Biçer Bayram, 2021) on insect.

\subsection{Experimental Design and}

\section{Analyzes}

Looking at Table 1; the TOS levels of insects in the larval stage nutrition on PSM increased by $0.50 \mu \mathrm{mol} / \mathrm{L}$ in those fed with $2 \mathrm{~g}$ (S.E \pm 0.1$)$ compared to the control group. The oil addition (HFD +2 g PSM) allowed this increase to increase to 2.00 $\mu \mathrm{mol} / \mathrm{L}$. When the larval TAS levels were compared to control, the addition of PSM to the nutrient saw a severe decrease in total antioxidant activity from 8 to $0.005 \mathrm{mmol} / \mathrm{L}$. According to the oxidative stress index, it is seen that stress starts with one gram of PSM and is highest at $2 \mathrm{~g}$.

During the pupae stage, it was determined that oxidation with oil use increased to $32 \mu \mathrm{mol} / \mathrm{L}$. The insect was found to be feeding on PSM, causing it to drop to $1 \mu \mathrm{mol} / \mathrm{L}$. High concentration PSM and nutrition showed that oxidation continued at the same rate. Although the level of antioxidants increased in groups with no oil used during the same period, the use of PSM with oil was observed to decrease the level of TAS $(1.00 \mathrm{mmol} / \mathrm{L})$. Although the oxidative stress index showed fluctuations during the pupal period, the combination of $2 \mathrm{~g}$ of PSM and oil allowed us to rate it as the group with the highest stress (Table 1). 
Table 1. TOS, TAS, and OSI values during fly developmental periods (standard errors are between $0.01-0.1$ and are not displayed in the table; df: 35; P:Significance level)

\begin{tabular}{|c|c|c|c|c|c|}
\hline G & & $\begin{array}{c}\text { TOS } \\
(\mu \mathrm{m} / \mathrm{L})\end{array}$ & $\begin{array}{c}\text { TAS } \\
(\mathrm{mm} / \mathrm{L})\end{array}$ & OSI & $P$ \\
\hline \multirow{6}{*}{$\begin{array}{l}\text { Larvae } \\
(\mathrm{n}: 20)\end{array}$} & 1 & 1.5 & 8.0 & 0.2 & \multirow{6}{*}{$\begin{array}{l}* 4 \text { and } 6 \text { are similar, and } \\
\text { different from others. }\end{array}$} \\
\hline & 2 & 1.8 & 9.0 & 0.2 & \\
\hline & 3 & 0.5 & 4.0 & 0.1 & \\
\hline & 4 & 2.0 & 0.1 & $20.0^{*}$ & \\
\hline & 5 & 1.0 & 4.0 & 0.3 & \\
\hline & 6 & 2.0 & 0.1 & $20.0^{*}$ & \\
\hline \multirow{6}{*}{$\begin{array}{l}\text { Pupae } \\
(n: 20)\end{array}$} & 1 & 24.5 & 2.0 & 12.3 & \multirow{6}{*}{$\begin{array}{l}1,3,4,5 \text { are similar, while } \\
\text { others are different. }\end{array}$} \\
\hline & 2 & 32.0 & 5.0 & $6.4^{*}$ & \\
\hline & 3 & 1.0 & 0.1 & 10.0 & \\
\hline & 4 & 32.0 & 3.0 & 10.7 & \\
\hline & 5 & 1.0 & 0.1 & 10.0 & \\
\hline & 6 & 32.0 & 1.0 & $32.0 * *$ & \\
\hline \multirow{6}{*}{$\begin{array}{c}\text { Female } \\
(\mathrm{n}: 20)\end{array}$} & 1 & 0.5 & 0.1 & 5.0 & \multirow{6}{*}{$\begin{array}{l}\text { All groups are different from } \\
\text { each other. }\end{array}$} \\
\hline & 2 & 1.5 & 0.1 & 18.8 & \\
\hline & 3 & 3.0 & 0.1 & 27.3 & \\
\hline & 4 & 5.5 & 0.2 & 32.4 & \\
\hline & 5 & 1.5 & 0.1 & 12.5 & \\
\hline & 6 & 8.5 & 0.2 & 53.1 & \\
\hline \multirow{6}{*}{$\begin{array}{l}\text { Male } \\
(\mathrm{n}: 20)\end{array}$} & 1 & 3.5 & 1.1 & 3.2 & \multirow{6}{*}{$\begin{array}{l}\text { All groups are different from } \\
\text { each other. }\end{array}$} \\
\hline & 2 & 4.5 & 3.6 & 1.3 & \\
\hline & 3 & 7.0 & 0.1 & 70.0 & \\
\hline & 4 & 3.0 & 0.4 & 7.5 & \\
\hline & 5 & 9.5 & 0.1 & 95.0 & \\
\hline & 6 & 8.5 & 0.1 & 106.0 & \\
\hline
\end{tabular}

TOS activity in females increased by 3-3.5 $\mu \mathrm{mol} / \mathrm{L}$ with the use of PSM, has dropped by as much as $1.5 \mu \mathrm{mol} / \mathrm{L}$ with the addition of oil. Oxidation at the highest concentration was determined to increase 8fold to $8.5 \mu \mathrm{mol} / \mathrm{L}$. However, TAS activity was found to be similar in female individuals with different concentrations of PSM intake. Oxidative stress index occurs at normal levels in female individuals in control groups, whereas feeding with PSM causes high stress and is even likely to produce lethal concentration (high oxidative stress) of HFD $+2 \mathrm{~g}$ of PSM (Table 1).
Although PSM increases oxidation in nutrition relative to TOS activities of the male individuals seen in Table 1 , it has been stated that oxidation along with fat is approximately 3 times greater. Because total antioxidants are not sufficient in male individuals, OSI values were observed to be high. Although the oxidative stress index varied inversely in concentrations in PSMfed men, the intake of PSM combined with high fat increased stress, resulting in reduced vitality and high oxidative stress. 

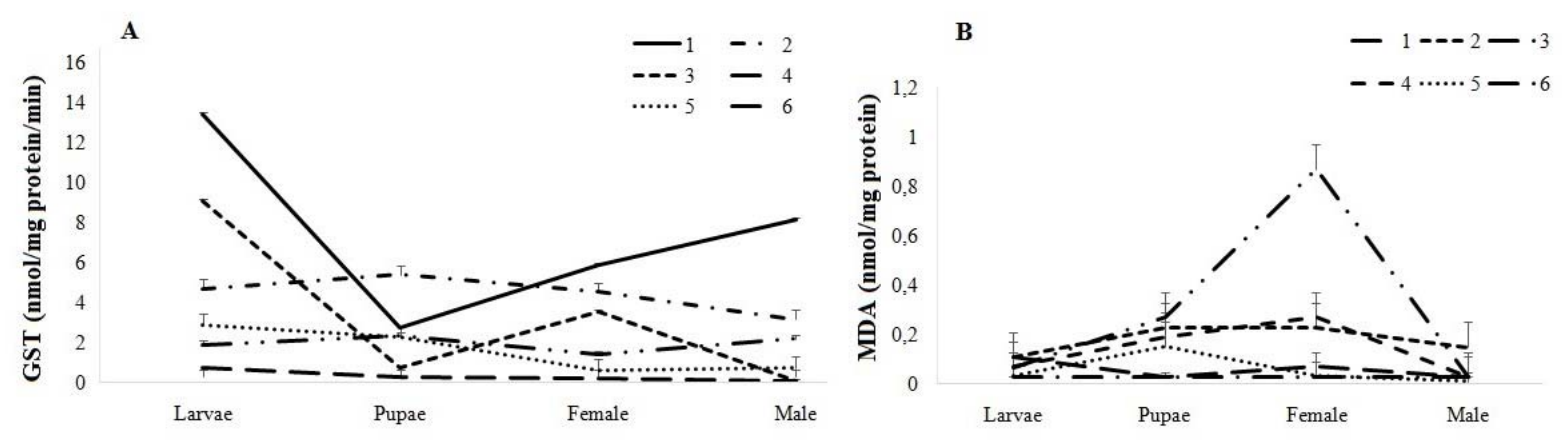

Figure 1. The adults antioxidant-resistance enzyme (A) and lipid peroxidation (B) during development stages, $\mathrm{P}>0.05$ (Kruskal-Wallis test)

According to Figure 1B, the amount of lipid peroxidation formed by larvae in the high-fat diet group was found to be the same as in the control group. Because of this result, PSM intake along with HFD for insects in the larval stage reduces the rate of lipid peroxidation. During the pupal stage, there are fluctuations in the amount of peroxidation, but it appears to increase the amount of MDA 5-9 times because of nutrition additional PSM to the fatty diet. While oxidation in the body fat of female individuals increased because of the amount of PSM, it was determined that with the use of fat this rising increased even higher, increasing of $0.87 \pm 0.1 \mathrm{nmol} / \mathrm{mg}$ protein in the highest concentration of 2 g PSM + HFD. In male individuals, the use of PSM + fat was determined not to affect peroxidation, although statistically similar results were achieved with control.

If MDA analysis is interpreted between stages (Figure 1B); while the peroxidation of the pupae and female individuals in the use of fat is excessive, the use of $0.05 \mathrm{~g}$ PSM does not appear to be effective between stages. There appears to be no change in female and male individuals despite reducing the amount of high fat intake MDA during the larval and pupal stage along with. The high amount of MDA in pupae and female individuals in high PSM groups indicates that females are more susceptible to oxidation. According to Figure 1A; Using PSM in the larval stage has decreased the resistance enzyme. With the addition of the high-fat diet, GST activity was further reduced, even dropping from 13.40 to $0.75 \pm 0.1 \quad(\mathrm{nmol} / \mathrm{mg}$ protein/min). During the pupal stage, pups in the HFD group were found to be about 2 times more resistant than control when comparing the resistance enzymes of insects to the control group. The resistance of pupae normalizes with increasing concentrations of PSM; GST activity decreased to $0.27 \pm 0.1$ (nmol / mg protein / $\mathrm{min}$ ) in pupae fed with increasing concentrations of HFD + PSM. 
GST activity has increased up to the use of 2 g PSM in females. However, individuals without nonresistant have formed. In men, resistance was not seen except for those who were fed only $2 \mathrm{~g}$ PSM.

If GST activity is interpreted between stages (Figure 1A); under normal conditions, it was found to be the most resistant stage (pupae $<$ female $<$ male $<$ larvae) larval stage. With high fat intake, the resistance of the pupae phase appears to be increasing. However, in other stages (larval, female, male) resistance was reduced. The most resistant larvae in feeding at $0.05 \mathrm{~g}$ PSM were seen in females in the second. Besides fat intake, those fed $0.05 \mathrm{~g}$ PSM were determined to have greater GST activity in the larval and pupae stages. At 2 g, pupae and male individuals had the most GST activity. However, it was determined that the high-fat diet reduces resistance in stages or even reduces to amount to be called absent in male individuals $(0.05$ $\mathrm{nmol} / \mathrm{mg}$ protein/min).

\section{Discussion}

Reactive oxygen species (ROS) cause oxidative stress by transporting molecular oxygen from the attack of unshared pairs of electrons; thus, fats, macromolecules such as proteins increase total oxidation in peroxide, and to Drosophila the toxic effect. (Guan et al.,
2017; Çolak and Uysal, 2018). Cellular oxidative damage is tried to be balanced with antioxidants taken from outside with cellular or nutrition. However, where the TAS mechanism is insufficient, a different response to stress $(\mathrm{TAS}<\mathrm{TOS}$, TAS $=$ TOS, TAS $>$ TOS) can be generated (Güneş, 2016 b). The amount of fat, protein, carbohydrates, vitamins found in the diet is as important in terms of removing tissue damage as the life parameters of insects (Adler and Bonduriansky, 2014; Unckless et al., 2015; Güneş, 2016a). The number of amino acids and proteins in flies fed rich nutrients by fatty diets can be reduced by being affected (Heinrichsen et al., 2014). So, experiments are planned considering the creation of obese model individuals. Our study shows that oxidative stress in the larval stage is highest at $2 \mathrm{~g}$. In the pupae stage, $2 \mathrm{~g}$ of PSM taken with a high-fat diet was identified as the group with the highest stress. Holometabolic insects feed in the larval and adult stages, the oxidative stress index is in the form of larvae $<$ pupae $<$ adult (Güneş, 2016b). Female individuals are normally known to be oxidated individuals due to mating and egg production (Le Goff et al., 2006). Although virgin females were used in the study; according to OSI, it is determined that it causes high stress by feeding females with PSM and is even likely to produce fatal effects (high oxidative 
stress) of HFD +2 g PSM (Table 1). Male individuals appear to have high OSI values because total antioxidants are not sufficient. According to OSI, the nutrition of males with PSM varies inversely depending on concentration, but the intake of fat and PSM caused high oxidative stress, resulting in reduced vitality in individuals.

Antioxidant enzymes in Drosophila; (SOD, E.C. 1.15.1.1), (CAT, E.C. 1.11.1.6), (GSH, E.C. 2.5.1.18), Glutathione reductase (E.C. 1.8.1.10), GST, Disulfite reductase (E.C. 1.8.1.14), Methionine sulfoxide reductase (E.C. 1.8.4.12), Thioredoxin peroxidase (E.C. 1.11.1.15) (Missirlis et al., 2003; Güneş, 2016a and b). For example, in some studies, it was reported that CAT and GR amounts decreased and GST activity changed in Drosophila due to xenobiotics and aging (Durusoy et al., 1995; Fışkın and Asma, 1996; Yeşilada and Gelegen, 2000). It has been reported that the larvae are prevented from pupation because of not only chemicals or aging but feeding and the amount of lipid may increase in adult individuals in case of starvation, or dietary carbohydrate change may cause oxidative stress in the insect. Low unsaturated dietary fats may increase the amount of MDA (De Moed et al., 1999; Jordens et al., 1999; Sisodia and Sing, 2012; Güneş, 2016b). The study found that the uptake of HFD and PSM in the larval stage decreased the amount of MDA while increasing the pupal stage by 5-9 times; while the amount of MDA due to the amount of PSM in females increased, the increase with the use of fat was seen to be even greater. In males, however, the use of PSM + oil was determined not to affect peroxidation. (Figure 1B). Adult individuals of 3-7 days are preferred for biochemical analyses. (Qiu et al., 2019). The three-day study of adults specifically determined that females were more open to lipid peroxidation than males (Figure 1B).

Pumpkin is a plant known as antioxidant effects (Nkosi et al., 2006; Perez Gutierrez, 2016). Chenopodium ambrosioides L. plant extracts can negatively affect Drosophila development and resistance (Wohlenberg and Lopes-da Silva, 2009). Which is more common in older and resistant individuals GST is a detoxifying enzyme and resistance enzyme (Piccoli et al., 2019). Using $10 \mathrm{mg}$ of plants such as Mangifera indica causes GST activity to decline in Drosophila (Etuh et al., 2019). It can cause an increase or decrease in GST activity depending on the experimental model and the texture analyzed (Piccoli et al., 2019). In this study was found that while resistance decreased with the use of oil and PSM in the larval stage, GST activity decreased because of nutrition with HFD + PSM despite the formation of resistant individuals at the pupal stage. In female individuals, nutrition with PSM in 
addition to the standard diet increased resistance, and the use of fat led to the formation of nonresistant individuals. With nutrition in males saw a decrease in the amount of GST. While GST activity is in the form of pupae $<$ female $<$ male $<$ larvae among stages, it appears to reduce resistance in the pupae in another stage with high fat intake. High PSM nutrition, on the other hand, was found to be the most GST activity in pupae and male individuals but reduced resistance in the HFD stages (Figure 1A). GST activity is considered a biomarker of toxicity for environmental pollutants (Liu et al., 2015). While GST activity is excessive in the larvae, it supports the study (Vorojeikina et al., 2017).

There has been growing interest in clarifying the role of nutritional habits in the nervous system in studies of inferences with model organisms. It appears that increased HFD and refined sugar-rich diet can reduce cognitive function because of changing dietary habits. Also, there is an increasing interest in antioxidant functional foods and treatments (Alzoubi et al., 2018b). The addition of apple pulp to nutrients was found to be beneficial against oxidative stress and liver damage in mice whose obesity model was created over 30 days with HFD (Chen et al., 2017). Continuing to feed mice with additional pineapple vinegar (produced from pineapple waste) to the HFD diet is known to lower cholesterol levels, lower blood glucose levels, increase antioxidant levels (Mohamad et al., 2020). Nephelium lappaceum L. shell waste added to the diet of obese individuals fed HFD is used to treat the damage caused by oxidative stress (Chung et al., 2018). While studies have shown that food waste can be useful in nutrition or in vivo as a nutrient environment, our study has not seen the same effect.

\section{Conclusion}

With high water retention capacity, PSM has been determined that high amounts cannot be tolerated by the insect, with small amounts of mixing of HFD-fed flies into the dietary environment increasing the insect's oxidative stress. Thus, although it was considered inappropriate to use PSM in the creation of a laboratory-fattening environment, it was believed that the resilient larval universe could be used in low quantities of PSM in designs as an experimental obesity model.

\section{Acknowledgment}

The study was produced from the second author's master's thesis. 


\section{References}

Alshehry GA (2020). Preparation and nutritional properties of cookies from the partial replacement of wheat flour using pumpkin seeds powder. WJEB 9(2): 48-56.

Alzoubi KH, Hasan ZA, Khabour OF, Mayyas FA, Al Yacoub ON, Banihani SA, Azab MA, Alrabadi N (2018a). The effect of high-fat diet on seizure threshold in rats: role of oxidative stress. Physiol behav 96: 1-7.

Alzoubi KH, Mayyas FA, Mahafzah R, Khabour OF (2018b). Melatonin prevents memory impairment induced by high-fat diet: role of oxidative stress. Behav Brain Res 336: 9398.

Bendor CD, Bardugo A, Pinhas-Hamiel O, Afek A, Twig G (2020). Cardiovascular morbidity, diabetes and cancer risk among children and adolescents with severe obesity. Cardiovas Diabetol 19(1): 1-14.

Blüher M (2020). Metabolically healthy obesity. Endocr Rev 41 (3): 405-420.

Bocharova OV, Teplyakova ED (2020). Children and adolescents' obesity is the 21 st century health problem. Kazan Med Journal 101(3): 381-388.

Chen L, Liu L, Li C, Hu C, Su F, Liu R, Zeng M, Zhao D, Liu J, Guo Y, Long J (2017). A mix of apple pomace polysaccharide improves mitochondrial function and reduces oxidative stress in the liver of high-fat diet-induced obese mice. Mol Nutr Food Res 61(3): 1600433.

Chung AP, Gurtu S, Chakravarthi S, Moorthy M, Palanisamy UD (2018). Geraniin protects high-fat diet-induced oxidative stress in Sprague Dawley rats. Front Nutr 5: 17.

Cormier RJ, Strang R, Menail H, Touaibia M, Pichaud N (2021). Systemic and mitochondrial effects of metabolic inflexibility induced by high fat diet in Drosophila melanogaster. Insect Biochem Mol Biol 103556.

Çankaya N, Muciz Ö (2017). A new functional additive obtained by using jet pulse filters: pumpkin seed membrane. International Congress on Medicinal and Aromatic Plants (Tabkon), 343, Konya/Turkey.

Çolak DA,Uysal H (2018). Evaluation of the lifespan of fruit fly Drosophila melanogaster exposed to dioxins. Agric Nat 21(5): 715.

De Moed GH, Kruitwagen CLJJ, De Jong G, Scharloo W (1999). Critical weight for the induction of pupariation in Drosophila melanogaster: genetic and environmental variation. $J$ Evol Biol 12(5): 852-858.

Durusoy M, Diril N, Bozcuk AN (1995). Age-related activity of glutathione S-transferase in three different genotypes of Drosophila melanogaster. Turkish J Biol 19: 337-342.

Erel O (2005). A new automated colorimetric method for measuring total oxidant status. Clin Biochem 38(12): 1103-1111.

Etuh MA, Aguiyi JC, Ochala SO, Simeon O, Oyeniran OI, Oshibanjo OD, Pam D (2019). The In vivo antioxidant protective activity of Mangifera indica cold aqueous leaf extract in Drosophila melanogaster. J Adv Biol Biotechnol 22(2): 1-7.

Filimonau V, Nghiem VN, Wang LE (2021). Food waste management in ethnic food restaurants. Int J Hosp Manag 92: 102731. 
Fışkıı K, Asma D (1996). Drosophila melanogaster Oregon (OR), yabanıl tipi (wt) ve vestigial (vg) mutantının ömür uzunluklarının karşılaştırılması. Antioksidatif enzimlerin ve ACE vitamin kompleksinin yaşlanma ile ilişkisi. Turkish J Biol 20: 99-110.

Genç C, Köse B (2019). Obesity and Impulsivity. Başkent University Faculty of Health Sci J 4(2): 95-104.

Guan XL, Wu PF, Wang S, Zhang JJ, Shen ZC, Luo H, Chen H, Long LH, Chen JG, Wang F (2017). Dimethyl sulfide protects against oxidative stress and extends lifespan via a methionine sulfoxide reductase A-dependent catalytic mechanism. Aging Cell 16(2): $226-236$.

Güneş E, Buyukguzel E (2017). Oxidative effects of boric acid on different developmental stages of Drosophila melanogaster Meigen, 1830 (Diptera: Drosophilidae). Turk Entomol Derg 41(1): 3-15.

Güneş E (2020). Extended longevity of Drosophila melanogaster by natural waste Citrullus lanatus seed. IJEPEM 3(4): 144-146.

Güneş E (2021). Antioxidant effects of ankaferd blood stopper doped polyvinyl pyrolidon in an experimental model created in insect. Food Chem Toxicol 148: 111935.

Güneş E, Biçer Bayram Ş (2021). Determining the effect of pumpkin seed membrane on survival, development longevity in animal model. KSÜ Agric Nat (accepted and in string).

Güneş E (2016a). Drosophila in food and nutrition studies. KSÜ Agric Nat 19(3): 236-243.

Güneş E (2016b). The effect of quinoa (Chenopodium quinoa Willd.) on the total oxidative stress Drosophila melanogaster Meigen (Diptera: Drosophilidae. KSÜ Agric Nat 19(3): 261-267.

Güneş E, Biçer Bayram Ş (2019). Kabak çekirdeği zarının ın vivo kullanımı. ganud international conference on gastronomy. Nutrition And Dietetics 303-310, Gaziantep/Turkey.

Güneysu S (2020). Change of domestic food waste and packages in COVID-19 process in Istanbul]. National Environ Sci Res J 3(4): 175-180.

Habig WH, Pabst MJ, Jakoby WB (1974). Glutathione S-transferases: the first enzymatic step in mercapturic acid formation. J Biol Chem 249(22): 7130-7139.

Hazir C, Bora G, Yurter HE (2021). Drosophila melanogaster Model in neurodegenerative disease research]. UUJFE 46(2): 237-245.

Heinrichsen ET, Zhang H, Robinson JE, Ngo J, Diop S, Bodmer R, Joiner WJ, Metallo CM, Haddad GG (2014). Metabolic and transcriptional response to a high-fat diet in Drosophila melanogaster. Mol Metab 3(1): 42-54.

Jain SK, Levine SN (1995). Elevated lipid peroxidation and vitamin E-quinone levels in heart ventricles of streptozotocin-treated diabetic rats. Free Radic Biol Med 18(2): 337-341.

Jordens RG, Berry MD, Gillott C, Boulton AA (1999). Prolongation of life in an experimental model of aging in Drosophila melanogaster. Neurochem Res 24(2): 227-233.

Koh T, Machino M, Murakami Y, Umemura N, Sakagami H (2013). Cytotoxicity of dental compounds towards human oral squamous cell carcinoma and normal oral cells. In Vivo 27(1): 85-95. 
Le Goff G, Hilliou F, Siegfried BD, Boundy S, Wajnberg E, Sofer L, Audant P, HffrenchConstant R, Feyereisen R (2006). Xenobiotic response in Drosophila melanogaster: sex dependence of P450 and GST gene induction. Insect Biochem Mol Biol 36(8): 674-682.

Liu H, He J, Zhao R, Chi C, Bao Y (2015). A novel biomarker for marine environmental pollution of pi-class glutathione S-transferase from Mytilus coruscus. Ecotoxicol Environ Saf 118: 47-54.

Llana-Ruiz-Cabello M, Gutiérrez-Praen D, Puerto M, Pichardo S, Jos Á, Cameán AM (2015). In vitro pro-oxidant/antioxidant role of carvacrol, thymol and their mixture in the intestinal Caco-2 cell line. Toxicol In Vitro 29(4): 647-656.

Lorizola IM, Furlan CP, Portovedo M, Milanski M, Botelho PB, Bezerra R, Capitani CD (2018). Beet stalks and leaves (Beta vulgaris L.) protect against high-fat diet-induced oxidative damage in the liver in mice. Nutrients 10(7): 872.

Lowry OH, Rosebrough NJ, Farr AL, Randall RJ (1951). Protein measurement with the folin phenol reagent. J Biol Chem 193: 265-275.

Lüersen K, Röder T, Rimbach G (2019). Drosophila melanogaster in nutrition research - the importance of standardizing experimental diets. Genes Nutr 14(1): 1-5.

Maduagwuna CA, Omale S, Etuh MA, Gyang SS (2020). Antioxidant activity of nHexane extract of Caryota no seed using Drosophila melanogaster model. J Advan Biol Biotechnol 39-47.

Majid AK, Ahmed Z, Khan R (2020). Effect of pumpkin seed oil on cholesterol fractions and systolic/diastolic blood pressure. Food Sci Technol (AHEAD) 40(3): 769-777.

Matthews BJ, Vosshall LB, Dickinson MH, Dow JA (2020). How to turn an organism into a model organism in 10 'easy'steps. J Exp Biol 223(Suppl_1).

Missirlis F. Rahlfs S, Dimopoulos N, Bauer H, Becker K, Hilliker A, Phillips JK, Jäckle H (2003). A putative glutathione peroxidase of Drosophila encodes a thioredoxin peroxidase that provides resistance against oxidative stress but fails to complement a lack of catalase activity. J Biol Chem 384(3): 463-472.

Mohamad NE, Yeap SK, Ky H, Liew NWC, Beh BK, Boo SY, Ho WY, Sharifuddin SA, Long K, Alitheen NB (2020). Pineapple vinegar regulates obesity-related genes and alters the gut microbiota in high-fat diet (HFD) C57BL/6 obese mice. Evid Based Compl Altern Med 1257962: 1-13.

Nainu F, Rahmatika D, Emran TB, Harapan H (2020). Potential application of Drosophila melanogaster as a model organism in COVID-19-related research. Front Pharmacol 11: 1415.

Nkosi CZ, Opoku AR, Terblanche SE (2006). Antioxidative effects of pumpkin seed (Cucurbita pepo) protein isolate in CCl4-Induced liver injury in low-protein fed rats. PUBDB 20(11): 935-940.

Özgün E, Özgün GS, Eskiocak S, Yalçın Ö, Gökmen SS (2013). Effect of L-carnitine on serum paraoxonase, arylesterase and lactonase activities and oxidative status in experimental colitis. Turk J Biochem 38(2):145-153.

Perez Gutierrez RM (2016). Review of Cucurbita pepo (pumpkin) its phytochemistry and pharmacology. Med Chem 6(1): 12-21.

Piccoli BC, Segatto ALA, Oliveira CS, da Silva FDA, Aschner M, Da Roch JBT (2019). Simultaneous exposure to vinylcyclohexene and methylmercury in Drosophila 
melanogaster: biochemical and molecular analyses. BMC Pharmacol Toxicol 20(1): 117.

Poças GM, Crosbie AE, Mirth CK (2020). When does diet matter? The roles of larval and adult nutrition in regulating adult size traits in Drosophila melanogaster. $J$ Insect Physiol 104051.

Qiu S, Wang S, Xiao C, Ge S (2019). Assessment of microalgae as a new feeding additive for fruit fly Drosophila melanogaster. Sci Total Environ 667: 455-463.

Sağlam Ö, Soylu Y (2019). Investigation of the relationship between childhood traumas and adult obesity due to child rearing styles. Turk J Social Work 3(2): 136-150.

Salama AA, Ismael NM, Bedewy M (2020). The anti-inflammatory and antiatherogenic in vivo effects of pomegranate peel powder: from waste to medicinal food. $J$ Med Food 24(2): $145-150$.

Siddique HR, Chowdhuri DK, Saxena DK, Dhawan A (2005). Validation of Drosophila melanogaster as an in vivo model for genotoxicity assessment using modified alkaline Comet assay. Mutagenesis 20(4): 285-290.

Sisodia S, Singh BN (2012). Experimental evidence for nutrition regulated stress resistance in Drosophila ananassae. PloS One 7(10): e46131.

Sun X, Seeberger J, Alberico T, Wang C, Wheeler CT, Schauss AG, Zou S (2010). Açai palm fruit (Euterpe oleracea Mart.) pulp improves survival of flies on a high fat diet. Exp Gerontol 45(3): 243-251.

Syed QA, Akram M, Shukat R (2019). Nutritional and therapeutic importance of the pumpkin seeds. Biomedical Journal of Scientific \& Technical Research 21(2): 15798-15803.

Töke LB, Ergülen A (2020). Approaches to solve the waste problem caused by globalization. Çukurova Üniversitesi IBBF Derg 24(2): 201-215.

Unckless RL, Rottschaefer SM, Lazzaro BP (2015). The complex contributions of genetics and nutrition to immunity in Drosophila melanogaster. PLoS Genet 11(3): 1-26.

Uysal H, Çelik H (2021). Determination of in vivo chronic effects of astaxanthin in different strains of Drosophila melanogaster. GUFBED 11(1): 135-146.

Valdez-Arjona LP, Ramírez-Mella M (2019). Pumpkin waste as livestock feed: Impact on nutrition and animal health and on quality of meat, milk, and egg. Animals 9(10): 769.

Vorojeikina D, Broberg K, Love TM, Davidson PW, van Wijngaarden E, Rand MD (2017). Editor's highlight: glutathione S-transferase activity moderates methylmercury toxicity during development in Drosophila. Toxicol Sci 157(1): 211-221.

Wohlenberg VC, Lopes-da-Silva M (2009). Effect of Chenopodium ambrosioides L. (Chenopodiaceae) aqueous extract on reproduction and life span of Drosophila melanogaster (Meigen) (Diptera: Drosophilidae). Bioscience 25(6): 129-132.

Yeşilada E, Gelegen L (2000). The effect of cadmium nitrate on the longevity of Drosophila Melanogaster. Turk J Biol 24(3): 593-600.

Zhang J, Liu X, Pan J, Zhao Q, Li Y, Gao W, Zhang Z (2020). Anti-aging effect of brown black wolfberry on Drosophila melanogaster and D-galactose-induced aging mice. $J$ Funct Foods 65: 103724. 